\title{
The Relationship between Academic Amotivation and Academic Achievement: A Study on Middle School Students
}

\section{Akademik Motivasyonsuzluk ile Akademik Başarı Arasındaki İlişki: Ortaokul Öğrencileri Üzerine Bir Çalışma}

\author{
İlhan İLTER*
}

Received: 25 December 2020

Research Article

Accepted: 29 June 2021

ABSTRACT: This study aimed to determine whether academic amotivation predicts academic achievement in middle-school students. In addition, it was examined whether the students' academic amotivation levels differed by their gender. Study sample consisted of 342 eighth-grade students from middle-schools in Kahramanmaras city in Turkey. Data were collected from Academic Amotivation Inventory. A simple-linear regression analysis was utilized to examine to what extent academic amotivation accounted for variance in academic achievement. The t-test analysis was used to determine whether amotivation types would differ by gender. Regression analysis results showed that academic amotivation was a significant negative predictor of academic achievement. Results also indicated that significant differences were found between the levels of academic amotivation of students by their gender. Boys were found to be more academically amotivated towards school-related activities and tasks than girls. The reason for the gender difference was that the level of amotivation due to effort beliefs, values placed on the tasks, and characteristics of the tasks, for boys were found significantly to be higher than for girls.

Keywords: Motivation, self-determination theory, amotivation.

ÖZ: $\mathrm{Bu}$ araştırma akademik motivasyonsuzluğun ortaokul öğrencilerinin akademik başarıları üzerinde etkisini belirlemeyi amaçlamıştır. Ayrıca çalışmada öğrencilerin akademik motivasyonsuzluk düzeylerinin cinsiyetlerine göre farklı1ık gösterip göstermediği incelenmiştir. Araştırmanın örneklemini Kahramanmaraş ilinde yer alan devlet ortaokullarında öğrenim gören 342 ortaokul sekizinci sınıf öğrencisi oluşturmuştur. Veriler Akademik Motivasyonsuzluk Ölçeği'nden elde edilmiştir. Akademik motivasyonsuzluğun akademik başarıdaki varyansı ne ölçüde açıkladığını belirlemek için basit bir doğrusal regresyon analizi; motivasyonsuzluk türlerinin öğrencilerin cinsiyetlerine göre farklılık gösterip göstermediğini belirlemek için t-testi analizi kullanılmıştır. Regresyon analizi sonuçları akademik motivasyonsuzluğun akademik başarının negatif yönlü anlamlı bir yordayıcısı olduğunu göstermiştir. Öğrencilerin cinsiyetlerine göre akademik motivasyonsuzluk düzeyleri arasında anlamlı düzeyde farklılıklar belirlenmiştir. Erkeklerin kızlara göre akademik faaliyetlere karşı daha fazla motivasyonsuzluk duygusu hissettikleri bulunmuştur. Cinsiyetten kaynaklanan farklılığın nedeni ise erkeklerin çaba inançlarındaki eksiklikler, görevlere yükledikleri değer eksikliği ve akademik görevlerin özellikleriyle ilgili algılarından kaynaklı motivasyonsuzluk düzeylerinin anlamlı düzeyde daha yüksek bulunmasıdır.

Anahtar kelimeler: Motivasyon, öz-belirleme kuramı, motivasyonsuzluk.

\footnotetext{
* Assoc. Prof. Dr., University of Kahramanmaraş Sutcu Imam, Kahramanmaraş, Turkey, iilter@ksu.edu.tr, https://orcid.org/0000-0002-1473-7172
}

Citation Information

İlter, İ. (2021). The relationship between academic amotivation and academic achievement: A study on middle school Students. Kuramsal Eğitimbilim Dergisi [Journal of Theoretical Educational Science], 14(3), 389-410. 
One of the most salient issues in education is student motivation and engagement (Guay \& Bureau, 2018; Kassaee \& Rowell, 2016). Motivation plays an important role in academic achievement and participation in the learning environment (Elliot \& Dweck, 2005; Linnenbrink \& Pintrich, 2002). Therefore, involving students in the learning process and discussions of motivation is more important now than ever (Schwan, 2021). However, maintaining students' engagement, interest, and motivation to learn is difficult (Reeve, 2013). The problem is that if students' psychological and developmental needs, which support motivation and increased self-determination for behavioral engagement, are not met, behavioral engagement may suffer, and students may struggle to successfully complete school-related tasks or activities and achieve desired educational outcomes (Ryan \& Deci, 2000).

\section{Self-Determination Theory (SDT)}

Self-determination theory (SDT) (Deci \& Ryan, 1985) is a model of organismic theory that explains important variables such as psychological growth, personality development, and effective performance. SDT is a theory of motivation and behavior change that can be used to explain motivation for a wide range of behaviors (Deci \& Ryan, 1985). It focuses on people's psychological basic needs and the various ways they express and satisfy them. Its major constructs are easily developed into strategies for assisting others in increasing their motivation to engage in a regular activity (Kilpatrick et al., 2002). SDT is particularly interested in how social-contextual factors contribute to individuals' thriving by meeting their basic psychological needs, which must be met in order for psychological interest, development, and well-being to be sustained (Ryan \& Deci, 2017). SDT defines that perceived autonomy and relatedness, as well as to perceived competence, can play an important role in fostering high-quality motivation, engagement and that satisfying the psychological needs for competence is particularly important in explaining quantity in motivation (Ryan \& Deci, 2002).

The first of SDT's basic needs is autonomy, which is defined as having an internal locus of control and believing that one's actions are freely chosen. A sense of mastery and the beliefs that we are effective at what we do define competence. Autonomy can be defined as a student's desire for control over decisions and a sense of choice within and between activities or tasks (Vansteenkiste et al., 2005). Competence in SDT refers to our basic need to feel effective and mastery, which is to be able to manifest as a learner's need to understand his or her work in order to successfully complete tasks (Ryan \& Deci, 2017, p.11). Relatedness is a construct defined by satisfaction and involvement in the social world. This need is satisfied by feeling a sense of connection with other people (Ryan \& Deci, 2011). SDT offers, all individuals want to feel autonomous, competent, and relatedness, and this desire leads to participation in activities that meet these basic needs (Kilpatrick et al., 2002).

High levels of perceived autonomy and perceived competence are the main proximal psychological factors implicated in intrinsic motivation (Deci \& Ryan, 1985). Autonomy, competence, and relatedness are essentials not only for optimal motivation but also for overall well-being (Ryan \& Deci, 2017, p.11). They are essential for psychological resilience, autonomy, performance, and warmth, as well as positive outcomes. However, failure to meet them will result in a lower quality relationship, feelings of incompetence in carrying out the required task, and decrease in well-being 
(Levesque et al., 2004). Satisfying these needs results in an increase in self-determined extrinsic motivation, an increase in intrinsic motivation, or a decrease in amotivation (i.e. lack of motivation), all of which contribute to student engagement and achievement (Niemiec \& Ryan, 2009). However, a lack of these three needs may contribute to amotivation in students, which leads to poor motivation and engagement, low academic self-esteem, poor educational outcomes, and undesirable academic behaviors in the classroom (Ryan \& Deci, 2017).

\section{Amotivation Based on Self-Determination Theory}

SDT is a well-studied motivation theory that holds that behavior can be motivated intrinsically, extrinsically, or amotivated (Deci \& Ryan, 1985). Amotivation is defined in the SDT as a lack of both intrinsic and extrinsic motivation to engage in a behavior or to execute a task (Ryan \& Deci, 2002). The degree to which people are passive, ineffective, or purposeless in relation to any given set of potential actions is defined as amotivation. It is thought to exist when individuals lack competence, perceive less autonomy, and it can indeed reflect the absence of self-determined motivation to act (Ryan \& Deci, 2017). Amotivation occurs in SDT when people do not intend to perform a behavior or act in a way that is not mediated by intentionality. This type of motivation arises from a person's perception that they cannot control outcomes of any action or that they cannot effectively perform the required actions. Amotivation, in return, contributes to performing poorly in school, having low academic self-esteem, and displaying behavioral problems in school (Ryan \& Deci, 2017). According to SDT, people who are amotivated may believe that their efforts will not result in the desired outcome, nor will help them feel competent, autonomous, or socially connected to their surroundings (Kilpatrick et al., 2002). Ryan and Deci (2002) noted that individuals will be amotivated if the need for competence and relatedness are not also met. Amotivation feeling severely limits the possibility of adopting and adhering to an activity.

\section{The Construct of Academic Amotivation Beliefs}

According to self-determination theory, academic amotivation beliefs occur for four distinct reasons (Legault et al., 2006). The first type of amotivation explains that individuals do not act when they believe they are effectively incapable of achieving goals they pursue for themselves. This type of amotivation occurs when a person believes they cannot control outcomes through any action, or when the person believes they are unable to perform an activity. This type of amotivation is based on beliefs (ability beliefs) about a perceived lack of ability (Ryan \& Deci, 2002, 2017). Inadequate perception of one's own competence in order to achieve their goals can lead to amotivation (Ryan \& Deci, 2000). The SDT proposes that ability beliefs are required for autonomy and competence in order for individuals to be intrinsically motivated (Vlachopoulos et al., 2013). The second type of amotivation is effort beliefs, which are perceptions that individuals do not want to expend the sustained effort required to perform and maintain a behavior. It's possible that they do not believe individuals can initiate or sustain the effort required by academic tasks. Amotivation can be triggered by the perception of a lack of desire and ability to exert the effort required by a particular behavior (Pelletier et al., 1999). The third type of amotivation occurs from a lack of academic values placed on the tasks (value beliefs) (Ryan, 1995). Individuals who have this type of amotivation have no value or interest in a task engagement. It results from a 
person's lack of an inner interest in behavior as well as a desire and energy for the results of behavior (Vansteenkiste et al., 2004). People may become amotivated when their behavior has no meaning or interest to them, especially when it does not relate to the satisfaction of psychological needs (Van Petegem et al., 2015). This type of amotivation may exist even if the person has the efficacy or competence to act and sustain it (Ryan \& Deci, 2017). The fourth type of amotivation is caused by perceptions of unappealing task or behavior characteristics (task characteristics beliefs). A lack of interest or stimulation in a task can lead to amotivation. A lack of interesting or stimulating qualities in a task, or whether it is boring, routine, difficult, or irrelevant, leads to amotivation, making it impossible to engage students in the task (Ainley et al., 2002). All these types of amotivation beliefs are conceptualized as complementary to the constructs of academic amotivation (Legault et al., 2006), and are generally associated with students' negative school outcomes (Niemiec \& Ryan, 2009; Vallerand et al., 1997; Volk, 2020).

The present study aimed to understand to what extent academic amotivation explained academic achievement among middle school students. Also, it was examined whether the academic amotivation levels of the students differed by their genders. The study was conducted for three important reasons. First, although the majority of previous research has focused on the relationships between many variables such as academic motivation, academic achievement, self-efficacy, and learning motivation (Areepattamannil, 2014; Çekim \& Aydın, 2018; Çetin, 2015; Datu \& Yang, 2019; Karaman et al., 2020; Klem \& Connell, 2004; Koca \& Dadand1, 2019; Liu \& Hou, 2018; Önder et al., 2014; Sicak \& Başören, 2015; Zorbaz, 2018), this study examined whether academic amotivation predicts academic achievement in middle school students. Secondly, in the existing literature in Turkey, little is known about the extent to which amotivation could predict academic achievement in a sample of middle school students (e.g., Akgümüş, 2020; Aydın \& Çekim, 2017). Indeed, there is a dearth of studies pertaining to academic amotivation among middle school students in Turkey. Fourthly, as gender is an effective factor in motivation and engagement (Meece et al., 2006; Mori \& Gobel, 2006), gender differences in academic amotivation among middle school students were investigated in this study. The main reason for considering gender is that the effect of gender on motivation in existing literature is unclear (e.g., Martin, 2003; Sorvo et al., 2017). Previous studies on the relationship between gender and motivation have yielded inconsistent results. While the results in some other research have shown in favor of girls (Ayub, 2010; Eymur \& Geban, 2011; Green-Demers et al., 2008; Martin, 2004), it is in favor of boys in some research (Karataş \& Erden, 2012; Lai et al., 2006; Michelli, 2013) in others, it has shown that gender did not affect motivation (Demir \& Arı, 2013; Ma, 1999; Yaratan \& Kasapoğlu, 2012). All of this suggests that more research is needed to investigate the effect of gender on student motivation. Investigating gender differences in amotivation types may provide middle school teachers with useful information about gender components influencing teaching and learning in their classrooms (Koka \& Sildala, 2018).

Given the lack of research on middle school students' constructs of academic amotivation, the present study aimed to address gaps in the literature by investigating the effect of academic amotivation would predict academic performance of middle school students. It is critical to broaden the investigation of academic amotivation in the 
middle school level. This is due to the fact that, depending on the characteristics of the middle school period, problems associated with decreased motivation and thus academic achievement may begin to decline (Gehlbach \& Roeser, 2002). Previous research has shown that as students progressed through the middle and high school grades, their academic engagement and motivation decreased (Lepper et al., 2005; Otis et al., 2005). Given that academic amotivation is theoretically characterized by a decrease in students' academic performance (Datu, 2017; Turner et al., 2009), this may cause serious problems in the transition of middle school students to secondary school. The following research questions guided the present study.

1. Is there a significant relationship between academic amotivation and academic achievement among middle school students?

2. Is academic amotivation a significant predictor of middle school students' academic achievement?

3. Is there significant differences between middle school students' academic amotivation types and their gender?

\section{Method}

\section{Research Design and Participants}

This cross-sectional survey study investigated the effect of academic amotivation on academic achievement among the sample of middle school students. In the cross-sectional survey, the researcher collects data at one point in time to assess certain variables immediately and quickly. This design has the advantage of measuring students' current motivation, beliefs or practices as well as their needs (Creswell, 2012). The sample for this study consisted of 342 eighth-grade students from public middle schools in Kahramanmaraş City, in Turkey, chosen at random from all public middle schools for the 2019-2020 school year. In this sample, 193 (56.43\%) of students were male, and $149(43.56 \%)$ were female. The easily accessible case sampling technique was used to determine the study group, which provides the researcher with convenient sampling and the ability to obtain data in a short period of time (Creswell, 2012). Students ranged in age from 13 to 14 , with a mean age of 13.5 years. Out of 342 participants, 177 (51.75\%) were at the middle socio-economic level, 82 (23.95\%) were at the high socio-economic level and $83(24.3 \%)$ were at the lower socio-economic level.

\section{Instruments}

Two different instruments were used in the present study. These were Grade Point Average (GPA) as defined as academic achievement and Academic Amotivation Scale.

\section{Academic Achievement}

Academic Achievement was defined as the participants' grade point average (GPA) at the end of the second semester (last) of the 2019-2020 school year. The participants' grade-point average was 73.8 ranging from 60.5 to 94.5 . GPAs in the Turkish education system for middle school range from 0 to 100 point on a 5-Likert scale (85-100=Very high level, 70-84.99=High level, 60-69.99=Medium level; 50- 
59.99=Low level, 0-49.99=Fail). Higher scores indicate higher levels of academic performance.

\section{Academic Amotivation Scale (AAS)}

The Academic Amotivation Scale (AAS) developed by Legault et al. (2006) and translated into Turkish (after the permission process) by Ilter (2019) was used to assess the academic amotivation levels of the participants. AAS assesses students' reasons for not wanting to study or do their homework using four academic amotivation types (4 items per sub-dimension) and 16 items. Items from the dimensions of ability beliefs (e.g. "Because the tasks demanded of me surpass my abilities"), effort beliefs (e.g. "Because I'm not energetic enough"), value placed on the task (e.g. "Because studying is not valuable to me"), and characteristics of the task (e.g. "Because I find that studying is boring"). These types of amotivation are measured using a 7-point Likert-type response scale anchored by 1 (does not correspond at all) to 7 (corresponds exactly), with students asked to indicate their level of agreement with AAS instrument items. Exploratory factor analysis (EFA) was performed to analyze the factor structure of the Turkish version of AAI using maximum-likelihood extraction and direct Oblimin rotation. EFA results for the AAI Turkish form showed that four factors had eigenvalues higher than 1 (ranged from 1.14 to 3.25 ) and accounted for $52.12 \%$ of total item variance. All items' factor loadings in the AAS-Turkish form ranged from .48 to .70, demonstrating the AAS Turkish form's high level of representability. Confirmatory factor analysis results revealed that scores from the AAS four-factor model were valid in the sample of Turkish middle school students: $\chi^{2}=1.30$, RMSEA $=.041, \mathrm{IFI}=.95$; $\mathrm{CFI}=.97, \mathrm{GFI}=.92$, IFI=.94. The internal consistency coefficient of dimensions of AASTurkish Version had were $\alpha=.77$ for the ability beliefs, $\alpha=.72$ for the effort beliefs, $\alpha=.81$ for the value placed on the task and $\alpha=.75$ for the characteristics of the task (Ilter, 2019). For the current sample in this study, the internal consistency coefficients of AAS were $\alpha=.88$ for ability beliefs, $\alpha=.87$ for effort beliefs, $\alpha=.81$ for value placed on and $\alpha=.83$ for characteristics of the task.

\section{Data Collection}

The study was approved by the local ethical committee. The researcher (the author) administered the AAS instrument and informed consent forms in the classroom setting during class time. He informed all participants that their participation was entirely voluntary, they could withdraw at any time, and all responses would remain anonymous. Thus, data were collected from a total of 388 middle school students. Two methods were used in the analysis for missing data in forms collected. First, students who did not respond to 5 or more items on the AAS were not included in the data set. It is a widely accepted common approach to dealing with missing data in the literature (Creswell, 2012). In this context, 17 out of 388 students' AAS form data were omitted from the data set and were not included in the study. Second, students with four or fewer missing responses were given mean values instead of missing values (Creswell, 2012; Tabachnick et al., 2007). As a result, 17 AAS forms were excluded from this study. Finally, 371 scale forms were included in the data analysis. 


\section{Data Analysis}

The SPSS 22.0 program was used to analyze the study data. Prior to data analysis, it was determined whether the data had a normal distribution. The Mahalanobis distance was used to determine whether or not there are extreme values that make normality (multivariate) and linearity assumptions difficult (Tabachnick et al., 2007). For each participant, the Mahalanobis distance value was compared to the Chisquare value at the $p<.001$ significance level (Tabachnick et al., 2007). Twenty-nine participants were identified as having multivariate extreme values and were excluded from the data analysis. As a result, all statistical analyses were carried out using data from 396 participants, despite the exclusion of 29 participants from the study. Skewness and kurtosis coefficients for all variables were examined in order to test the data's normality assumptions. The skewness coefficients for the academic amotivation subdimensions ranged from -1.065 to -.874 , and the kurtosis coefficients ranged from - .848 to.789. The coefficient of skewness for academic achievement was found to be -.839 and the coefficient of kurtosis was .812 . The fact that all of these values were between 1.5 and +1.5 indicated that all of the variables in the sample had a normal distribution (Tabachnick et al., 2007). The Pearson product-moment correlation coefficient was used to examine the relationships between academic amotivation types and academic achievement. A simple linear regression analysis was used to determine whether academic amotivation would predict the academic achievement. Independent t-test analysis was used to determine whether gender differences play a role significantly in types of academic amotivation of students. In all analyzes, the significance level was accepted as $p<.05$.

\section{Ethical Procedures}

This study received ethics approval from the Humanities Sciences Ethical Review Committee of Kahramanmaraş Sütçü İmam University (Dated 18.08.2020 and numbered E. 30974).

\section{Results}

The first research question was whether there was a significant relationship between each of type of academic amotivation and academic achievement. Pearson product-moment correlation analysis was performed to examine the relationship between these variables. Results are displayed in Table 1 .

Table 1

Descriptive Statistics and Correlations for Variables

\begin{tabular}{lccccccc}
\hline Variables & AB & EB & VPT & CT & AA & $M$ & $S D$ \\
\hline AB & & $.420^{* *}$ & $.388^{* *}$ & $.416^{* *}$ & $-.390^{* *}$ & 3.43 & 5.56 \\
EB & & & $.481^{* *}$ & $.512^{* *}$ & $-.417^{* *}$ & 3.88 & 4.32 \\
VPT & & & & $.474^{* *}$ & $-.355^{* *}$ & 3.33 & 3.97 \\
CT & & & & & $-.307^{* *}$ & 2.75 & 3.36 \\
AA & & & & & & 70.51 & 11.58
\end{tabular}

$*^{*} p<.001, \mathrm{AB}=$ Ability beliefs, $\mathrm{EF}=\mathrm{Effort}$ beliefs, $\mathrm{VPT}=$ Value placed on the task, $\mathrm{CT}=$ Characteristics of the task, $\mathrm{AA}=\mathrm{Academic}$ achievement 
The correlation analysis revealed that each type of academic amotivation was significantly negatively correlated with academic achievement at the $p<.001$ level, as shown in Table 1. The correlation coefficients were $r=-.390, p<.001$ for ability beliefs, $r=-.417, p<.001$ for effort beliefs, $r=-.355, p<.001$ for value attributed to the task, and $r=-.307, p<.001$ for characteristics of the task. The highest correlation coefficient was found between effort beliefs and academic achievement.

The second research question of the present study was whether participants' academic amotivation would predict their academic achievement. A simple linear regression analysis was used to whether academic amotivation predicted participants' academic achievement. Academic amotivation was identified as the predictive variable and academic achievement as the predicted variable. Regression analysis results are presented in Table 2 .

Table 2

The Regression Analysis Results

\begin{tabular}{lccc}
\hline & \multicolumn{3}{c}{ Academic achievement } \\
\cline { 2 - 4 } Predictor variable & $B$ & $S E$ & $\beta$ \\
\hline Academic amotivation (Total) & -.551 & .055 & $-.421^{* *}$ \\
\hline
\end{tabular}

$* * p<.001$

As can be seen in Table 2, the regression analysis results indicated that academic amotivation significantly predicted middle school students' academic achievement $(\beta=-$ $421, p<.001)$. When the standardized coefficient and $\mathrm{t}$ value were examined, amotivation was found to be a negative significant predictor of academic achievement $\left(R=.390, R^{2}=.15, p<.001\right)$. Overall regression model was significant $(\mathrm{F}=12.012, p<.001)$. Academic amotivation accounted for $15 \%$ of the variance in academic achievement.

Table 3

Results of the t-test for Participants' Types of Academic Amotivation by Their Gender

\begin{tabular}{lccccc}
\hline Variable & Gender & $N$ & $M$ & $S D$ & $t$ \\
\hline \multirow{2}{*}{ VPT } & Boy & 193 & 2.237 & 1.743 & $2.917^{*}$ \\
& Girl & 149 & 2.182 & 1.607 & \\
AB & Boy & 193 & 2.201 & 1.025 & 1.254 \\
& Girl & 149 & 1.996 & 1.147 & \\
CT & Boy & 193 & 2.731 & 1.275 & $3.732^{*}$ \\
& Girl & 149 & 2.446 & 1.839 & \\
EB & Boy & 193 & 2.542 & 1.941 & $2.487^{*}$ \\
& Girl & 149 & 2.368 & 1.916 & \\
Total & Boy & 193 & 2.572 & 1.824 & $3.261^{*}$ \\
& Girl & 149 & 2.250 & 1.803 & \\
\hline
\end{tabular}

$* p<.05$

(C) 2021 AKU, Kuramsal Eğitimbilim Dergisi - Journal of Theoretical Educational Science, 14(3), 389-410 
Based on the gender variable, the t-test analysis results in Table 3 shows that there were significant differences $(p<.05)$ for the value of the task $(t=2.917 ; p<.05)$, for the characteristics of the task $(t=3.732 ; p<.05)$, for effort beliefs $(t=2.487, p<.05)$ and for total academic amotivation score $(t=3.261 ; p<.05)$. However, no significant difference was found in the ability beliefs $(p>.05)$. When comparing each type of amotivation, the characteristics of the task had the highest mean score among other amotivation types in both boys $(M=2.73, S D=1.27)$ and girls $(M=2.44, S D=1.839)$. The type of ability beliefs was found to be the lowest mean score for both boys $(M=2.20$, $S D=1.021)$, and girls $(M=1.99, S D=1.839)$. The mean score of the effort beliefs was found to be high for both boys $(M=2.54, S D=1.94)$ and girls $(M=2.36, S D=1.91)$. For boys $(M=2.57, S D=1.824)$ total academic amotivation score were higher than for girls $(M=2.25, S D=1.80)$. Boys scored higher than girls in all amotivation types. This finding indicated that boys were more academically amotivated toward academic activities than did girls.

\section{Discussion and Conclusion}

Results of this study showed that 1) academic amotivation was negatively related to academic achievement indicating that higher academic amotivation was, in turn, associated with lower academic achievement, 2) academic amotivation was a significant negative predictor of academic achievement and it accounted for $15 \%$ of the variance in academic achievement. The results were consistent with previous research results (e.g., Balkis, 2018; Legault et al., 2006; Otis et al., 2005; Taylor et al., 2014; Volk, 2020), which similarly was found that level of amotivation of students negatively predicted their academic achievement. One possible explanation for academic amotivation as a negative predictor of academic achievement within the present study could be an influence on students' experience with different types of academic amotivation. First, in the SDT, amotivation is the lowest form of self-determination, resulting in one's feelings of his abilities poorly to carry out the required academic tasks (Ryan \& Deci, 2017). A lack of ability beliefs reduces one's sense of competence and autonomy, which lowers engagement and academic outcomes (Wigfield \& Eccles, 2000). This is also consistent with Bandura's (1997) contention that the higher the perceived competence related to academic abilities, the more ambitious the challenges that follow. Battin-Pearson et al. (2000) noted that if students perceive uncertainty in their academic skills, they believe that they will not succeed. Second, amotivation due to effort beliefs may lead to various undesirable academic results, including academic disconnection, low engagement, and poor performance (Chouinard, 2001; Perry \& Hamm, 2017; Tempelaar et al., 2015). SDT describes effort beliefs that depict one's capacity and desire to invest the energy required by a behavior (Pelletier et al., 1999; Ryan \& Deci, 2002). Students may become amotivated even if they believe in their abilities if they do not believe they can maintain the effort required to complete their tasks. As found in this study, previous research has confirmed that a lack of belief in one's own effort is a predictor of academic detachment (Patrick et al., 1993), poor academic performance (Kearney, 2016) and use of metacognitive abilities (Aydin, 2016). Researchers noted that academic detachment is caused by a lack of ability or desire to exert effort for the behavior or activity (Eccles et al., 1993; Patrick et al., 1993). Shen et al. (2010) concluded that amotivation was found to be a negative predictor of students' classroom effort behavior in Physical Education. Therefore, lack 
of ability beliefs and lack of effort beliefs may undermine intrinsic motivation, resulting in low-quality performance and emotional well-being (Ryan \& Deci, 2002). Third, one of the key determinants of achievement and motivation expectations is the configuration of values (Ryan \& Deci, 2017). Task values refer to one's assessment of how interesting, important, and useful a task is (Boiche' \& Sarrazin, 2007; Wigfield \& Eccles, 2002). Ryan and Deci (2000) defined a person who does not believe that values related to a task that provide any intrinsic value, personal benefit value, or attainment value will not execute the task. According to SDT, if an action does not have an internal value or benefit, people cannot feel integrated with the action; thus, they may become amotivated. Researchers found that the values attributed to the tasks are positively related to cognitive performance (Choi et al., 2010). Also, the expectancy-value theory argues that the more intrinsic value a person attributes to an activity, the greater their insistence, participation and performance in the activity becomes (Wigfield et al., 2016). Fourth, when the characteristics of activity and context do not meet the psychological needs of students, they are likely to lead to amotivation (Ryan \& Deci, 2017). Academic disengagement may occur if the unappealing characteristics of academic tasks in a school setting are linked to feelings of boredom (Ainley et al., 2002; Ntoumanis, 2001; Ntoumanis et al., 2004). Students are likely to be disconnected if the feathers of schoolbased tasks or activities do not direct, engage, or stimulate them (Ford \& Roby, 2013). Tasks that are considered too challenging for students can cause boredom by decreasing students' motivation and affecting their achievement negatively (Ahmed et al., 2013; Standage et al., 2005). All of these findings indicate that amotivation is a risk factor for middle school students' academic achievement, which has contributed to poor academic performance (Legault et al., 2006) and should be taken into account by teachers before students transfer to high school.

In the study, the results revealed that boys had significantly higher levels of academic amotivation than girls. This study further identified a clear gender difference in academic amotivation favoring boys. Boys seemed to be more inclined to develop a sense of amotivation. Specifically, this was due to the fact that boys scored significantly higher than girls on all types of academic amotivation, including ability beliefs, effort beliefs, value placed on the task and characteristics of the task. On the other hand, both genders showed high levels of amotivation for two types: effort beliefs and task characteristics. This finding supports the notion that there are significant differences in the context of amotivation between boys and girls. Some previous research has shown that boys have more motivational deficits than girls (e.g. Akandere et al., 2010; Alçı \& Tümkaya, 2019; Arcagök, 2016; Ertem, 2006; Grouzet et al., 2006; Pajares \& Valiante, 2002; Sicak \& Başören, 2015; Tuncer et al., 2018; Yerlikaya, 2014; Yurt \& Bozer, 2015). In light of previous research findings, the likelihood of this question being correct is possible. For example, Rowe and Rowe (1999) found that, when compared to girls, boys are more reluctant to participate in activities and put forth less effort to solve difficult problems in-class. Why boys are more amotivated to do academic activities than girls can be explained by the findings of Martin's (2004) study, which found that girls have a greater desire to do corporate together, to be a part of an activity, to concentrate on learning activities and to be more resilient in the face of failure, to adapt to the learning environment. Martin (2004) concluded that girls are more likely than boys to adopt a learning or mastery focus, plan school studies, effectively plan and 
manage academic activities, and challenge failure, whereas boys are more prone to selfhandicapping in tasks. Nevertheless, it should be noted that the findings in this study are limited to the study's sample. More research is needed to investigate the reasons for gender differences in amotivation among middle school students, including qualitative data and obtaining more detailed results based on the investigation of possible reasons for gender differences in the results obtained.

\section{Implications}

Results of this study have yielded important theoretical and practical implications. Results showed that academic amotivation was found to have a significant effect in predicting academic achievement of middle school students. This finding suggests that amotivation may pose a risk to the academic achievement of middle school students and should be taken seriously in the school setting. When students suffer from academic amotivation, it may cause them to avoid academic tasks. This may result in poor performance or failure (Pintrich \& Schunk, 2002). To eliminate academic amotivation of students, there is a need for interventions to support their engagement and academic achievement that take into account their psychological needs, including ability beliefs, effort beliefs, and academic value beliefs.

Teachers should play a larger role in creating a classroom environment in which teachers accept students who want to participate in class and actively demonstrate their abilities in learning activities in order to increase students' effort beliefs. This has the potential to influence students' effort beliefs and perceptions of task values (Fryer \& Bovee, 2016). Teachers should give students opportunities to take charge of their learning and look for structures to internalize in the classroom. This encourages students' initiative and autonomy. Wherever possible, teachers should provide the optimal support for students to encourage their efforts, and students should be encouraged to take responsibility for their learning and behavior, which increases feelings of autonomy and competence (Alley, 2019; Deci et al., 1996). Teachers can allow students to set learning objectives that will motivate them to work hard to improve their academic performance. To encourage students' efforts, teachers should strive to promote their autonomy and competence, consider their experience, and provide supportive feedback. Teachers can scaffold amotivated students who attribute their failures to their efforts to improve their autonomy and feelings of competence by using strategy instruction components including motivation, modeling, guided practices, and independent practices to support feelings of their students' autonomy and competence (Slavin, 2003). Students will be able to try to rely on their efforts and learn new strategies as they develop new skills. Supporting students by organizing their efforts may increase their responsibility for optimal learning tasks that support selfdetermination needs, which in turn will also support their academic achievement (Alley, 2019).

Students' ability beliefs are an important source of constructing in the dynamics of motivational development for learning and behavior choices (Eccles, 2005; Wigfield $\&$ Eccles, 2002). Teachers should pay close attention to their students' self-perceptions of their abilities. For classroom practice of the teachers, intervention programs could be used to increase students' ability beliefs. For example, Tier 2 provides targeted prevention and academic intervention strategies for students who are amotivated (Fuchs 
\& Fuchs, 2006). Individualized academic support, performance monitoring, and mentoring practice are among these strategies (Sinclair et al., 2005). Teachers can use these strategies to help students gain academic abilities that will improve or change their practicing, performance, and behavior. The more students who are involved in defining these skills, the more likely students are to see school as a living space where they can reflect on what they have learned. Such intervention strategies can serve as a motivator for students to improve their competence and effort beliefs in their academic abilities.

Teachers have an impact on students' perceptions of their autonomy and competencies, which helps to reduce amotivation. Teachers have, therefore, important responsibilities for their students' learning and behavior. They can encourage amotivated students to communicate more openly in the classroom and to engage in academic, social, and extracurricular activities that allow them to demonstrate their academic skills and effort. Together with their students, teachers can plan curricular activities and tasks that are considered valuable for students and specific to their talents and success expectations. When students fail in their academic abilities, teacher can reduce these student's level of amotivation by providing empowering opportunities for students to experience autonomy and achievement, such as constructive notifications that they are sufficient, what they can do if they put forth effort, and that they can be successful (Locke \& Latham, 2002). This supports students to develop positive, achievement-related self-perceptions, values, and a sense of school belonging (Ryan \& Deci, 2002). Believing that the student is progressing well in line with their abilities will also meet their intrinsic motivation, curiosity, psychological needs (Pintrich \& Schunk, 2002). Students who believe in their abilities will feel more competence and autonomy in taking advantage of challenging opportunities provided by their surroundings. According to previous research, teachers who support students' academic skills and autonomy encourage higher levels of intrinsic motivation in their students (Flink et al., 1990). Students' sense of their abilities can be positively influenced when teachers develop and share positive expectations and beliefs that their students can effectively complete school-related tasks and achieve curriculum outcomes (Slavin, 2003).

In order to strengthen students' task value beliefs, teachers should plan academic activities that are specific to students' achievement beliefs and approaches to learning and that can be deemed valuable for students. They should design meaningful tasks for their students that focus on interest, internal pleasures, and self-improvement rather than comparing them to their peers. Skinner et al. (1990) noted that engaging amotivated middle-school students more fully in learning would be possible if the students were provided with autonomy-supportive activities and were more active and meaningful, thus students will be more autonomously motivated for learning and engagement. Teachers should also explain the reasons and benefits of the activities to emphasize the importance of learning outcomes and improving new skills (Pintrich \& Schunk, 2002). They can promote higher quality engagement, achievement, and positive experiences for students by emphasizing the personal significance or perceived value of academic tasks. Creating a mastery-focused task-based environment that incorporates at least one form of value, such as intrinsic value, attainment value, or utility value, may also aid in improving students' task value beliefs. When students believe that the learning activity will benefit them, they will value the activity more by increasing their sense of duty and, as a result, putting in more effort. Students who recognize the importance of the 
task and personally support it are more likely to take action. The expectancy-value theory defines that task value beliefs are good predictors of students' achievement behaviors, including choice, persistence, and effort. Students who consider a task useful, important, or enjoyable generally put in more time and effort (Kahraman \& SungurVural, 2014; Wigfield \& Eccles, 2002).

In this study, amotivation due to task characteristics had the highest average score in both genders. This finding has shown the possibility that perceptions about the characteristics of academic tasks may further provoke amotivation in students. Teachers can use effective methods to motivate students both individually and in groups to create interesting and encouraging academic activities that increase students' beliefs and competencies in their academic skills. Teachers can recognize students for reaching their full potential by designing activities that encourage all students to work efficiently. When a task lacks impressive and interesting features, or if it is perceived as boring and difficult, it may be difficult to engage the student in the activity. This situation may be a contributing factor to amotivation (Ainley et al., 2002). If the activity experience does not arouse the student's value, skills, or willingness to learn, it is possible that the student will not choose to participate in this activity. It is also possible that such an activity will be discontinued or ignored. As a result, unappealing schoolwork can lead to academic disengagement as well as a reluctance to put forth effort. Unappealing schoolwork can cause students to see the school as an unattractive place (Kearney, 2016). Results suggest that teachers and students can collaborate to plan academic activities that are valuable for students in selecting or designing academic activities and are specific to their success expectations and abilities.

In the present study, the results showed that boys were found to have felt more academically amotivated toward academic activities at school than were girls. Accordingly, teachers should be responsible for encouraging boys to avoid negative beliefs about their ability and efforts because these behaviors are associated with higher levels of amotivation. Teachers should also provide boys with positive informational feedback and relatedness supports on their learning progress and do so to benefit their competence needs. Teachers should be responsible for both boys and girls in class in order to encourage them to avoid equally negative motivational processes such as feelings of autonomy or self-determination and feelings of effect or competence, as these behaviors are also associated with higher levels of amotivation. Teachers should foster students' feelings of autonomy and intrinsic motivation.

\section{Limitations and Further Research Suggestions}

There were some limitations to this study that should be addressed in future studies. First, because a cross-sectional research design was used, the study limits to draw causal inferences about the relationship between academic amotivation and academic achievement among middle school students. In the future, longitudinal designs should be used to investigate the sequential ordering of these explanatory and outcome variables. Second, the study data was limited to responses of the participants to the sub-dimension items in the AAS instrument. Self-reported data were collected from this study that was a threat to internal validity. Although self-reported measures could be used effectively, participants might have been dishonest or misleading in their responses. To address this limitation, future research should use alternative measures 
reasons of students' academic amotivation (e.g., students-report and teacher-report data). In addition, a larger sample size that included the accessible population would yield more reliable data representative of a more diverse population. Finally, because the data was collected from Turkish middle school students in the eighth grade, the findings may not be generalizable to other contexts. Future research among middle school populations from other socio-cultural contexts and different grades may be warranted to test the generalizability of the findings of this study.

\section{Conflicts of Interest}

There are no conflicts of interest in this study. 


\section{References}

Ahmed, W., Van der Werf, G., Kuyper, H., \& Minnaert, A. (2013). Emotions, selfregulated learning, and achievement in mathematics: A growth curve analysis. Journal of Educational Psychology, 105(1), 150-161. https://doi.org/10.1037/a0030160

Ainley, M., Hidi, S., \& Berndoff, D. (2002). Interest, learning, and the psychological processes that mediate their relationship. Journal of Educational Psychology, 94, 545-561. https://doi.org/10.1037/0022-0663.94.3.545

Akandere, M., Özyalvaç, N. T., \& Duman, S. (2010). The attitudes of the students in secondary education to physical education lesson and the investigation of their success motivations (Konya Anatolian High School Sample). The Journal of Selcuk University Social Sciences Institute, 24, 1-10.

Akgümüş, M. (2020). Ortaokul öğrencilerinin akademik motivasyonlarının yordayıcısı olarak okul atmosferi ve sosyo-demografik değişkenler [School atmosphere and socio-demographic variables as predictors of academic motivations of secondary school] [Unpublished master's thesis]. Ondokuz Mayıs University, Samsun.

Alçı, M., \& Tümkaya, S. (2019). The prediction level of school belonging for prospective teachers and academic motivation for professional instructor competence they perceived. Çukurova University Journal of Social Sciences Institute, 28(2), 241-256. https://doi.org/10.35379/cusosbil.591857

Alley, K. M. (2019). Fostering middle school students' autonomy to support motivation and engagement, Middle School Journal, 50(3), 5-14. https://doi.org/10.1080/00940771.2019.1603801

Arcagök, S. (2016). The relationship between perceptions of autonomy support of fourth grade students towards the social studies course and their motivation, entrepreneurship and creativity [Unpublished doctoral dissertation thesis]. Çanakkale Onsekiz Mart University, Çanakkale.

Areepattamannil, S. (2014). Relationship between academic motivation and mathematics achievement among Indian adolescents in Canada and India. The Journal of General Psychology, 141(3) 247-262.

Aydin, S. (2016). An analysis of the relationship between high school students' selfefficacy, metacognitive strategy use and their academic motivation for learn biology. Journal of Education and Training Studies, 4(2), 53-59. http://dx.doi.org/10.11114/jets.v4i2.1113

Aydın, S., \& Çekim, Z. (2017). Examining the relationship between the secondary school students' academic achievement and perception of achievement and their motivation to learn science. Mustafa Kemal University Journal of Social Sciences Institute, 14(39), 458-470.

Ayub, N. (2010). Effect of intrinsic and extrinsic motivation on academic performance. Pakistan Business Review, 1-2(2), 363-372.

Balkis, M. (2018). Academic amotivation and intention to school dropout: the mediation role of academic achievement and absenteeism. Asia Pacific Journal of Education, 38(2), 257-270. https://doi.org/10.1080/02188791.2018.1460258

Bandura, A. (1997). Self-efficacy: The exercise of control. New York: Freeman. 
Battin-Pearson, S., Newcomb, M. D., Abbott, R. D., Hill, K. G., Catalano, R. F., \& Hawkins, J. D. (2000). Predictors of early high school dropout: A test of five theories. Journal of Educational Psychology, 92(3), 568-582.

Boiche', J., \& Sarrazin, P. (2007). Self-determined motivation, perceived conflict and instrumentality and exercise adherence: A 6-month prospective study. Psychologie Française, 52(4), 417-430. https://doi.org/10.1016/j.psfr.2007.02.002

Choi, J., Fiszdon, J. M., \& Medalia, A. (2010). Expectancy-value theory in persistence of learning effects in schizophrenia: Role of task value and perceived competency. Schizophrenia Bulletin, 36(5), 957-965. https://doi.org/10.1093/schbul/sbq078

Chouinard, R. (2001). Les changements annuels de la motivation envers les mathe'matiques au secondaire selon l'a^ge et le sexe des e'le'ves [Annual changes in motivation for mathematics in high school according to age and gender]. Canadian Journal of Behavioural Science, 33, 25-37.

Creswell, J. W. (2012). Educational research: Planning, conducting, and evaluating quantitative ( $4^{\text {th }}$ ed.). Upper Saddle River: Prentice Hall. Merrill.

Çekim, Z., \& Aydın, S. (2018). Investigation of the relations between middle school student's motivation to learn science and use of learning strategies Kirlkkale University Journal of Social Sciences, 8(2), 451-468.

Çetin, B. (2015). Academic motivation and self-regulated learning in predicting academic achievement in college. Journal of International Education Research, 11(2), 95-106.

Datu, J. A. D. (2017). Peace of mind, academic motivation, and academic achievement in Filipino high school students. The Spanish Journal of Psychology, 20, E22. https://doi.org/10.1017/sjp.2017.19

Datu, J. A. D., \& Yang, W. (2019). Academic buoyancy, academic motivation, and academic achievement among Filipino high school students. Current Psychology, 1-8. https://doi.org/10.1007/s12144-019-00358-y

Deci, E. L., \& Ryan, R. M. (1985). Intrinsic motivation and self-determination in human behavior. New York: Plenum Press.

Deci, E. L., Ryan, R. M., \& Williams, G. C. (1996). Need satisfaction and the selfregulation of learning. Learning and Individual Differences, 8(3), 165-183. https://doi.org/10.1016/S1041-6080(96)90013-8

Demir, M. K., \& Ar1, E. (2013). Assessing levels of academic motivation of preservice teachers in terms of various variables. Journal of Theory and Practice in Education, 9(3), 265-279.

Eccles, J. S. (2005). Subjective task value and the Eccles et al. model of achievement related choices. In A. J. Elliot, \& C. S. Dweck (Eds.), Handbook of competence and motivation (pp. 105-121). Guilford Press.

Eccles, J. S., Wigfield, A., Midgley, C., Reuman, D., MacIver, D., \& Feldlaufer, H. (1993). Negative effects of traditional middle schools on students' motivation. The Elementary School Journal, 93, 553-574.

Elliot, A. J., \& Dweck, C. S. (2005). Handbook of competence and motivation. New York, NY: Guilford. 
Ertem, H. (2006). Investigation of secondary education students' motivation types (intrinsic and extrinsic) and levels toward chemistry courses based on some variables [Unpublished master's thesis]. Balıkesir University. Balıkesir.

Eymur, G., \& Geban, Ö. (2011). An investigation of the relationship between motivation and academic achievement of pre-service chemistry teachers. Education and Science, 36(161), 246-254.

Flink, C., Boggiano, A. K., \& Barrett, M. (1990). Controlling teaching strategies: Undermining children's self-determination and performance. Journal of Personality and Social Psychology, 59, 916-924. https://doi.org/10.1037/0022-3514.59.5.916

Ford, V. B., \& Roby, D. E. (2013). Why do high school students lack motivation in the classroom? Global Education Journal, 2, 101-113.

Fryer, L. K., \& Bovee, H. N. (2016). Supporting students' motivation for e-learning: Teachers matter on and off line. The Internet and Higher Education, 30, 21-29. https://doi.org/10.1016/j.iheduc.2016.03.003

Fuchs, D., \& Fuchs, L. S. (2006). Introduction to response to intervention: What, why, and how valid is it? Reading Research Quarterly, 41, 93-99.

Gehlbach, H., \& Roeser, R. W. (2002). The middle way to motivating middle school students: Avoiding false dichotomies. Middle School Journal, 33(3), 39-46. https://doi.org/10.1080/00940771.2002.11494673

Green-Demers, I., Legault, L., Pelletier, D., \& Pelletier, L. G. (2008). Factorial invariance of the Academic Amotivation Inventory (AAI) across gender and grade in a sample of Canadian high school students. Educational and Psychological Measurement, 68(5), 862-880. https://doi.org/10.1177/0013164407313368

Grouzet, F. M., Otis, N., \& Pelletier, L. G. (2006). Longitudinal cross-gender factorial invariance of the Academic Motivation Scale. Structural Equation Modeling, 13(1), 73-98. https://doi.org/10.1207/s15328007sem1301_4

Guay, F., \& Bureau, J. S. (2018). Motivation at school: Differentiation between and within school subjects matters in the prediction of academic achievement. Contemporary Educational Psychology, 54, 42-54. https://doi.org/10.1016/j.cedpsych.2018.05.004

Ilter, I. (2019). Adaptation of the academic amotivation scale into Turkish culture [Akademik motivasyonsuzluk ölçeğinin Türk kültürüne uyarlanması]. Ankara University Journal of Faculty of Educational Sciences, 52(1), 192-224. https://doi.org/10.30964/auebfd.459675

Kahraman, N., \& Sungur-Vural, S. (2014). The contribution of gender, socio-economic status and socio-cultural influence to Turkish students' task value beliefs in science. Research in Education, 91(1), 30-44.

Karaman, M. A., Vela, J. C., \& Eşici, H. (2020). Middle school students' academic motivation in Turkey: Levels of perfectionism and self-efficacy. Middle School Journal, 51(5), 35-45. https://doi.org/10.1080/00940771.2020.1814624

Karataş, H., \& Erden, M. (2012). Bilingual equivalence, validity and reliability of academic motivation scale [Akademik motivasyon ölçeğinin dilsel eşdeğerlik, geçerlik ve güvenirlik çalişmasi]. e-Journal of New World Sciences Academy, 7(4), 983-1003. 
Kassaee, A. M., \& Rowell, G. H. (2016). Motivationally informed interventions for atrisk STEM students. Journal of STEM Education, 17 (3), 77-84.

Kearney, C. A. (2016). Managing school absenteeism at multiple tiers: An evidencebased and practical guide for professionals. Oxford University Press.

Kilpatrick, M., Hebert, E., \& Jacobsen, D. (2002). Physical activity motivation: A practitioner's guide to self-determination theory. Journal of Physical Education, Recreation \& Dance, 36-41. https://doi.org/10.1080/07303084.2002.10607789

Klem, A. M., \& Connell, J. P. (2004). Relationships matter: Linking teacher support to student engagement and achievement. Journal of School Health, 74, 262-273.

Koca, F., \& Dadand1, İ. (2019). The mediation roles of test anxiety and academic motivation in the relationship between academic self-efficacy and academic achievement. Elementary Education Online, 18(1). 241-252. https://doi.org/10.17051/ilkonline.2019.527207

Koka, A., \& Sildala, H. (2018). Gender differences in the relationships between perceived teachers' controlling behaviors and amotivation in physical education. Journal of Teaching in Physical Education, 37(2), 197-208.

Lai, P. Y. M., Chan, K. W., \& Wong, K. Y. A. (2006). A study of intrinsic motivation, achievement goals and study strategies of Hong Kong Chinese secondary students. Australian Association for Research in Education (AARE) Conference. http://publications.aare.edu.au/06pap/lai06321.pdf

Legault, L., Green-Demers, I., \& Pelletier, L. G. (2006). Why do high school students lack motivation in the classroom? Toward an understanding of academic amotivation and the role of social support. Journal of Educational Psychology, 98(3), 567-582. https://doi.org/10.1037/0022-0663.98.3.567

Lepper, M. R., Corpus, J. H., \& Iyengar, S. S. (2005). Intrinsic and extrinsic motivational orientations in the classroom: Age differences and academic correlates. Journal of Educational Psychology, 97(2), 184-196. https://doi.org/10.1037/0022-0663.97.2.184

Levesque, C., Zuehllce, A. N., Stanelc, L. R., \& Ryan, R, M. (2004). Autonomy and competence in German and American university students: A comparative study based on self-determination theory. Journal of Educational Psychology, 96(1), 6884. https://doi.org/10.1037/0022-0663.96.1.68

Linnenbrink, E. A., \& Pintrich, P. R. (2002). Motivation as an enabler for academic success. The School Psychology Review, 31, 313-327. https://doi.org/10.1080/02796015.2002.12086158

Liu, Y., \& Hou, S. (2018). Potential reciprocal relationship between motivation and achievement: A longitudinal study. School Psychology International, 39(1), 38-55. https://doi.org/10.1177/0143034317710574

Locke, E. A., \& Latham, G. P. (2002). Building a practically useful theory of goal setting and task motivation: A 35-year odyssey. American Psychologist, 57(9), 705717. https://doi.org/10.1037/0003-066X.57.9.705 
Ma, X. (1999). A meta-analysis of the relationship between anxiety toward mathematics and achievement in mathematics. Journal for Research in Mathematics Education, 30(5) 520-540. https://doi.org/10.2307/749772

Martin, A. J. (2003). The student motivation scale: Further testing of an instrument that measures school students' motivation. Australian Journal of Education, 47(1), 88106. https://doi.org/10.1177/000494410304700107

Martin, A. J. (2004). School motivation of boys and girls: Differences of degree, differences of kind or both? Australian Journal of Psychology, 56(3), 133-146.

Meece, J. L., Glienke, B. B., \& Burg, S. (2006). Gender and motivation. Journal of School Psychology, 44, 351-373. https://doi.org/10.1016/j.jsp.2006.04.004

Michelli, M. P. (2013). The relationship between attitudes and achievement in mathematics among fifth grade students [Unpublished doctoral dissertation thesis]. University of Southern Mississippi.

Mori, S., \& Gobel, P. (2006). Motivation and gender in the Japanese EFL classroom. System, 34(2), 194-210. https://doi.org/10.1016/j.system.2005.11.002

Niemiec, C. P., \& Ryan, R. M. (2009). Autonomy, competence, and relatedness in the classroom: Applying self-determination theory to educational practice. Theory and research in Education, 7(2), 133-144. https://doi.org/10.1177/1477878509104318

Ntoumanis, N. (2001). A self-determination approach to the understanding of motivation in physical education. British Journal of Educational Psychology, 71, 225-242. https://doi.org/10.1348/000709901158497

Ntoumanis, N., Pensgaard, A., Martin, C., \& Pipe, K. (2004). An idiographic analysis of amotivation in compulsory school physical education. Journal of Sport and Exercise, 26(2), 197-214. https://doi.org/10.1123/jsep.26.2.197

Önder, İ., Beşoluk, Ş., İskender, M., Masal, E., \& Demirhan, E. (2014). Circadian preferences, sleep quality and sleep patterns, personality, academic motivation and academic achievement of university students. Learning and Individual Differences, 32, 184-192. https://doi.org/10.1016/j.lindif.2014.02.003

Otis, N., Grouzet, F. M., \& Pelletier, L. G. (2005). Latent motivational change in an academic setting: A 3-year longitudinal study. Journal of Educational Psychology, 97, 170-183.

Pajares, F. I, \& Valiante, G. (2002). Gender differences in writing motivation and achievement of middle school students: A function of gender orientation? Contemporary Educational Psychology, 26(3), 366-381. https://doi.org/10.1006/ceps.2000.1069

Patrick, B. C., Skinner, E. A., \& Connell, J. P. (1993). What motivates children's behavior and emotion? Joint effects of perceived control and autonomy in the academic domain. Journal of Personality and Social Psychology, 65(4), 781-791. https://doi.org/10.1037/0022-3514.65.4.781

Pelletier, L. G., Dion, S., Tucson, K., \& Green-Demers, I. (1999). Why do people fail to adopt environmental behaviors? Toward a taxonomy of environmental amotivation. Journal of Basic and Applied Social Psychology, 29, 2481-2504. https://doi.org/10.1111/j.1559-1816.1999.tb00122.x 
Perry, R. P., \& Hamm, J. M. (2017). An attribution perspective on competence and motivation: Theory and treatment interventions. In A. Elliot, C. Dweck, \& D. Yeager (Eds.), Handbook of competence and motivation: Theory and applications (2nd ed.). New York: Guilford Press.

Pintrich, P. R., \& Schunk, D.H. (2002). Motivation in education theory, research, and applications. Upper Saddle River: New Jersey, NJ: Columbus, Ohio.

Reeve, J. (2013). How students create motivationally supportive learning environments for themselves: The concept of agentic engagement. Journal of Educational Psychology, 105, (3), 579-95. https://doi.org/10.1037/a0032690

Rowe, K. J., \& Rowe, K. S. (1999). Investigating the relationship between students' attentive-inattentive behaviors in the classroom and their literacy progress. International Journal of Educational Research, 31, 1-38. https://doi.org/10.1016/S0883-0355(98)00068-8

Ryan, R. M. (1995). Psychological needs and the facilitation of integrative processes. Journal of Personality, 63, 397-427. https://doi.org/10.1111/j.14676494.1995.tb00501.x

Ryan, R. M., \& Deci, E. L. (2000). Self-determination theory and the facilitation of intrinsic motivation, social development, and well-being. American Psychologist, 55(1), 68-78.

Ryan, R. M., \& Deci, E. L. (2002). An overview of self-determination theory: An organismic dialectical perspective. E. L. Deci, R. M. Ryan (Ed.), Handbook of selfdetermination research (pp. 3-36). Rochester, NY: University of Rochester Press.

Ryan, R. M., \& Deci, E. L. (2011). A self-determination theory perspective on social, institutional, cultural, and economic supports for autonomy and their importance for well-being. In Human autonomy in cross-cultural context (pp. 45-64). Springer, Dordrecht.

Ryan, R. M., \& Deci, E. L. (2017). Self-determination theory: Basic psychological needs in motivation, development, and wellness. New York, NY: Guilford.

Schwan, A. (2021). Perceptions of student motivation and amotivation. The Clearing House: A Journal of Educational Strategies, Issues and Ideas, 94(2), 76-82.

Shen, B., Wingert, R. K., Li, W., Sun, H., \& Rukavina, P. B. (2010). An amotivation model in physical education. Journal of Teaching in Physical Education, 29(1), 7284. https://doi.org/10.1123/jtpe.29.1.72

Sicak, A., \& Başören, M. (2015). An investigation of high school students academic motivation in related to various variables (Bartın Samples). Bartın University Journal of Faculty of Education, 4(2), 548-560. https://doi.org/10.14686/buefad.v4i2.1082000239

Sinclair, M. F., Christenson, S. L., \& Thurlow, M. L. (2005). Promoting school completion of urban secondary youth with emotional or behavioral disabilities. Exceptional children, 71(4), 465-482. https://doi.org/10.1177/001440290507100405

Skinner, E. A., Wellborn, J. G., \& Connell, J. P. (1990). What it takes to do well in school and whether I've got it: The role of perceived control in children's 
engagement and school achievement. Journal of Educational Psychology, 82, 2232.

Slavin, R. E. (2003). Educational psychology: Theory into practice (7th edit.). New York, NY: Ally and Bacon.

Sorvo, R., Koponen, T., Violainen, H., Aro, T., Räikkönen, E., Peura, P., \& Aro, M. (2017). Math anxiety and its relationship with basic arithmetic skills among primary school children. British Journal of Educational Psychology, 87(3), 309327. https://doi.org/10.1111/bjep.12151

Standage, M., Duda J., \& Ntoumanis, N. (2005). A test of self-determination theory in school physical education. British Journal of Educational Psychology 75, 411-433. https://doi.org/10.1348/000709904X22359

Tabachnick, B. G., Fidell, L. S., \& Ullman, J. B. (2007). Using multivariate statistics. Boston, MA: Pearson.

Taylor, G., Jungert, T., Mageau, G. A., Schattke, K., Dedic, H., Rosenfield, S., \& Koestner, R. (2014). A self-determination theory approach to predicting school achievement over time: The unique role of intrinsic motivation. Contemporary Educational Psychology, 39(4), 342-358. https://doi.org/10.1016/j.cedpsych.2014.08.002

Tempelaar, D. T., Rienties, B., Giesbers, B., \& Gijselaers, W. H. (2015). The pivotal role of effort beliefs in mediating implicit theories of intelligence and achievement goals and academic motivations. Social Psychology of Education, 18(1), 101-120. https://doi.org/10.1007/s11218-014-9281-7

Tuncer, G., Yelken, T. Y., \& Tanriseven, I. (2018). The investigation of the relationship between academic motivations and inquiry skills of philosophy students. Mersin University Journal of the Faculty of Education, 14(3), 1156-1175. https://doi.org/10.17860/mersinefd.397603

Turner, E. A., Chandler, M., \& Heffer, R. W. (2009). The influence of parenting styles, achievement motivation, and self-efficacy on academic performance in college students. Journal of College Student Development, 50(3), 337- 346. https://doi.org/10.1353/csd.0.0073

Vallerand, R. J., Fortier, M.S., \& Guay, F. (1997). Self-determination and persistence in a real-life setting: Toward a motivational model of high school dropout. Journal of Personality and Social Psychology, 72, 1161-1176. https://doi.org/10.1037/00223514.72.5.1161

Van Petegem, S., Soenens, B., Vansteenkiste, M., \& Beyers, W. (2015). Rebels with a cause? Adolescent defiance from the perspective of reactance theory and selfdetermination theory. Child Development, 86(3), 903-918. https://doi.org/10.1111/cdev.12355

Vansteenkiste, M., Lens, W., Dewitte, S., de Witte, H., \& Deci, E. L. (2004). The "why" and "why not" of job search behaviour: Their relation to searching, unemployment experience, and well-being. European Journal of Social Psychology, 34(3), 345-363. https://doi.org/10.1002/ejsp.202

Vansteenkiste, M., Zhou, M., Lens, W., \& Soenens, B. (2005). Experiences of autonomy and control among Chinese learners: Vitalizing or immobilizing? 
Journal of Educational Psychology, 97(3), 468-483. https://doi.org/10.1037/00220663.97.3.468

Vlachopoulos, S. P., Katartzi, E. S., \& Kontou, M. G. (2013). Fitting multidimensional amotivation into the self-determination theory nomological network: Application in school physical education. Measurement in Physical Education and Exercise Science, 17(1), 40-61. https://doi.org/10.1080/1091367X.2013.741366

Volk, D. T. (2020). An examination of the relationship between school climate, selfdetermined academic motivation, and academic outcomes among middle and high school students (Unpublished doctoral dissertation). University of Connecticut. New York.

Wigfield, A., \& Eccles, J. (2000). Expectancy-value theory of achievement motivation. Contemporary Educational Psychology, 25(1), 68-81. https://doi.org/10.1006/ceps.1999.1015

Wigfield, A., \& Eccles, J. (2002). The development of competence beliefs, expectancies for success, and achievement values from childhood through adolescence. In A. Wigfield \& J. Eccles (Eds.), Development of achievement motivation (pp. 91-120). San Diego, Academic Press. https://doi.org/10.1016/B978-012750053-9/50006-1

Wigfield, A., Tonks, S., \& Klauda, S. L. (2016). Expectancy-value theory. In K. R. Wentzel \& A. Wigfield (Eds.), Handbook of motivation at school (pp. 55-75). New York, NY: Routledge.

Yaratan, H., \& Kasapoğlu, L. (2012). Eighth grade students' attitude, anxiety, and achievement pertaining to mathematics lessons. Procedia Social and Behavioral Sciences, 46, 162-17. https://doi.org/10.1016/j.sbspro.2012.05.087

Yerlikaya, İ. (2014). The study of motivation of primary and secondary school students into education in terms of various varieties. Journal of History School (JOHS), 7, 773-795.

Yurt, E., \& Bozer, E. N. (2015). The adaptation of the academic motivation scale for Turkish context. Gaziantep University Journal of Social Sciences, 14(3), 669-685. https://doi.org/10.21547/jss.256759

Zorbaz, O. (2018). Student and school level factors affecting drop out risks of high school students. [Unpublished doctoral dissertation thesis]. Ankara: Hacettepe University. 